九州大学学術情報リポジトリ

Kyushu University Institutional Repository

\title{
Production Structure of White Pine Cutting in Korea
}

\section{Kang, Hag Mo}

Department of Forest Environmental Science, Chonbuk National University

Choi, Soo Im

Department of Forest Resources, Sunchon National University

Sato, Noriko

Laboratory of Forest Policy, Division of Forest Environment and Management Sciences, Department of Agro-environmental Sciences, Faculty of Agriculture, Kyushu University

Kim, Hyun

Jeonbuk Forest Environment Research Institute

https://doi.org/10.5109/25213

出版情報: 九州大学大学院農学研究院紀要. 57 (2)，pp.507-515，2012-09-20. Faculty of Agriculture, Kyushu University

バージョン：

権利関係 : 


\title{
Production Structure of White Pine Cutting in Korea
}

\author{
Hag Mo KANG ${ }^{1}$, Soo Im CHOI $^{2 *}$, Noriko SATO and Hyun KIM ${ }^{3}$ \\ Laboratory of Forest Policy, Division of Forest Environment and Management Sciences, \\ Department of Agro-environmental Sciences, Faculty of Agriculture, \\ Kyushu University, Fukuoka 812-8581, Japan \\ (Received April 27, 2012 and accepted May 10, 2012)
}

\begin{abstract}
Korean major needle leaf tree and broad leaf tree account for 2,681 thousand and 1,659 thousand. The Korean tree species include $75 \%$ of larch, $16 \%$ of pine, $3 \%$ of rigida, and $3 \%$ of white pine, but for Gyeonggi-do, the number of white pine was the most among needle leaf trees and accounted for $34 \%$ of them. However, several conditions including lack of labors, insufficient forest management, and low wood price act as factors making the environment of forest management difficult. Accordingly, this study performed a study to identify management problems and promote activation of future forest management, against forest owners of white fine cutting in Gapyeong-gun, Gyeonggi-do, which was known as a representative pine nut producing district, accounting for $9 \%$ of the nationwide white pine forest area, 230 thousand ha. As results of the study, it was found that it was impossible practically to fell forest trees by its owner because of problems such as lack of labors and equipments and most of them didn't know existence and role of the Forestry Association well. One-sided presentation of timber price by timber dealers is likely to cause low profit of the forest owners and may be leaded to lowering of their forest management willing. Thus, it seems that more active action of the forestry association is required for efficient control and management of artificial forest in future and forest commencement such as pruning and thinning should be done in order to raise the price of forest tree price in the pulp material level to the level of timber price. And above everything, it was identified that in order to prepare insufficient financial resources for forest commencement, it was required to try to bring up whose purpose of forest possession was not maintenance of ancestral burial ground or property value, but true forest management.
\end{abstract}

Keywords: cutting, Korea, production structure, property, white pine

\section{INTRODUCTION}

The government has concentrated its investment including forest commencement on forest promotion zone for supply of industrial materials and expansion of forest product income source and earmarked 40.9 billion won of working expenses in 2010 for raising value added by strengthening competitive power of shore period income forest products. And it supported long-term low interest fund to forest owners and forestry workers timely to raise the competitive power of forestry and prepared 82.8 billion won of general fund for forest projects. In addition, the government strives for activation of forestry management by promoting various projects such as reorganization of national support system for private forest, rearing sincere forest managers and forest successors as the key managing body, construction of income safety net for forestry workers against natural disasters, improvement of forestry tax system, fostering the Forestry Association as a institution for forestry workers and forest owners, reorganization toward user centered technology training system, construction of private forest management system, and expansion of forest management plan establishment in the 5th Basic Forest Plan

\footnotetext{
1 Department of Forest Environmental Science, Chonbuk National University, Chonju, 561-756, Korea

2 Department of Forest Resources, Sunchon National University, Suncheon, 540-742, Korea

${ }^{3}$ Jeonbuk Forest Environment Research Institute, Jinan-gun, 561-756, Korea

* Corresponding author (E-mail: sooim@sunchon.ac.kr)
}

for uplift of private forest competitive power. However low profitability, insufficient fund, lack of labor, imperfection of stable outlet, and low price of timer still make the forestry management difficult and the forestry managers insist mitigation of regulation for forest use, expansion of project fund support, and expansion of forestry technology guidance and management information supply as roles of the government (Kang and Kohroki, 2008a; Kang and Kohroki, 2008b; Seo et al., 1999; Kim, 2010).

Accordingly, the purpose of this study is to identify management problems to promote activation of future forest management, against forest owners of white fine cutting in Gapyeong-gun, Gyeonggi-do, which was known as a representative pine nut producing district, accounting for $9 \%$ of the nationwide white pine forest area, 230 thousand ha.

\section{MATERIALS AND METHODS}

First for the cutting status of Gapyeong-gun for 5 years from 2005 to 2009, it was found that number of cutting forest owners was 414 man-days, its cutting area was $765 \mathrm{ha}$, and its cutting volume was $22,560 \mathrm{~m}^{3}$. Among the above results, $73 \%$ of the forest owners, $77 \%$ of the area, and $47 \%$ of the volume was thinning and by tree species, white pine was the most, accounting for $60 \%$ of the forest owners, $67 \%$ of the area, and $50 \%$ of the volume. The cutting forest owners which was 414 mandays consisted of 175 man-days of resident forest owner and 239 man-days of absentee forest owner and by their management scales, the forest owners possessing 1 3 
and less than 1 ha accounted for the majority as $43 \%$ and 41\% (Gapyeong-gun. 2010a; Gapyeong-gun. 2010b; Gapyeong-gun. 2010c).

Besides, although a direct survey was conducted against 93 forest owners located in Gapyeong-gun who executed cutting for 5 years from 2005 to 2009, it was successful on only 41 persons with reasons such as missing, refusal, long term outing, and moving out to other districts. By regions, the subjects consisted of 6 persons in Gapyeong-eup, 14 persons in Seolak-myeon, 3 persons in Cheongpyeong-myeon, 2 persons in Buk-myeon, 7 persons in Ha-myeon, and 9 persons in Sang-myeon.

This survey was executed for 2 months from early March to middle May 2010 and its contents included white pine cutting area, cutting tree volume, timber sales income, forest commencement record, operating body of cutting, forest management plan, forest management conditions and difficulties. Data were compared and analyzed by ages and forest management scales.

\section{RESULTS AND DISCUSSIONS}

\section{Forest area by tree species and white pine forest in Korea}

Total area of needle forest and broad-leaf forest in Korea is 4,340 thousand ha, which consists of 2,681 thousand (62\%) of needle forest and 1,659 thousand (38\%) of broad leaf forest. White pine forest took $5 \%$ of total forest area and $9 \%$ of needle forest and by regions, Gangwon-do has 77 thousand ha, followed by Gyeonggi-do with 65 thousand ha and Gyeongsangbuk-do with 28 thousand ha. For regions with higher ratio of white pine forest in needle forest, Gyeonggi-do has the highest ratio of white pine forest as 34\%, followed by Gangwon-do with 16\%

Table 1. Forest area by main tree species

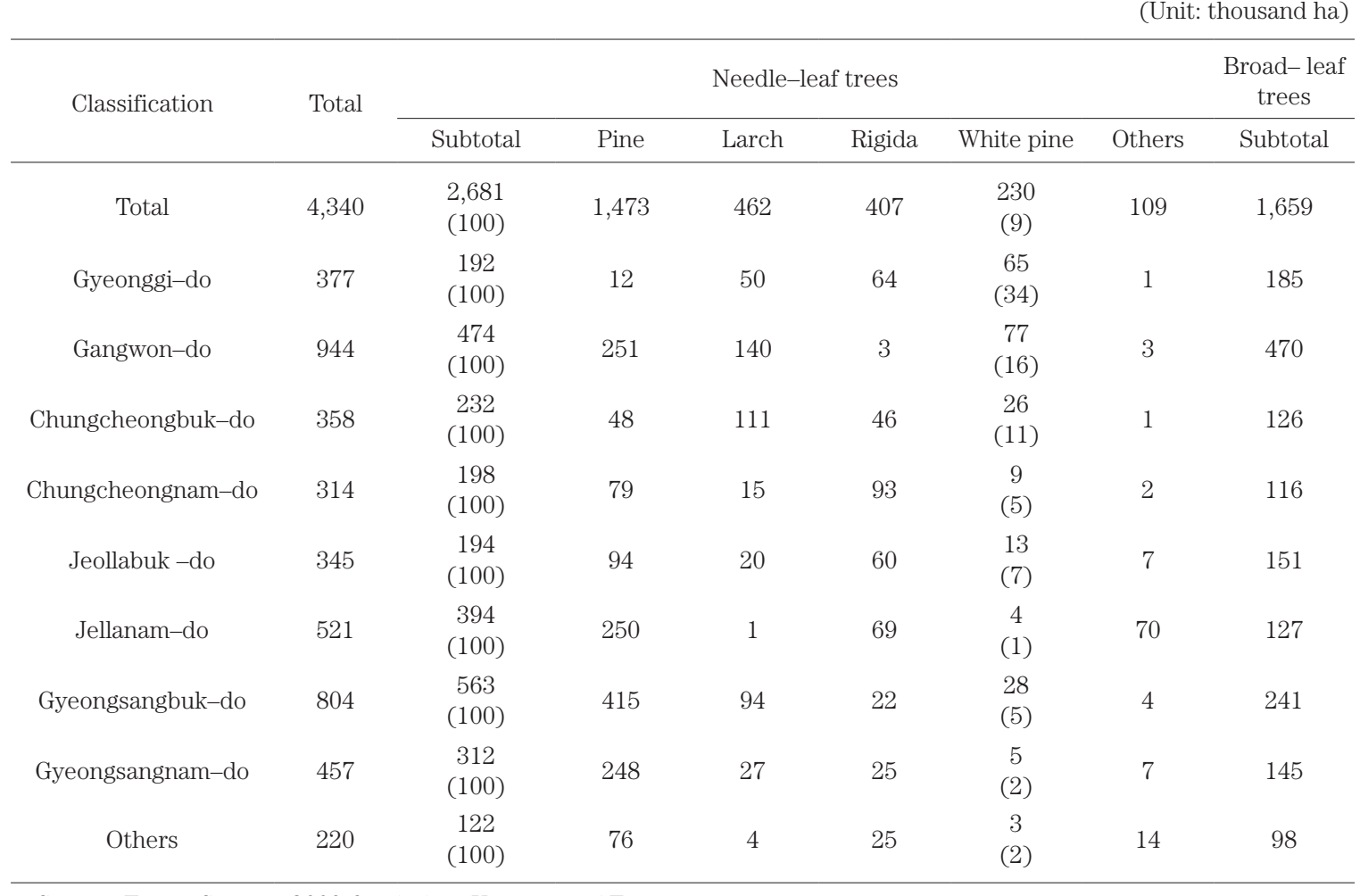

Source: Forest Service. 2009 Statistical Yearbook of Forestry

Note: The value in ( ) is the component ratio.

Table 2. Supply amount of domestic wood materials for lumbering

(Unit: $\mathrm{m}^{3}$ )

\begin{tabular}{cccccccc}
\hline & & Larch & Pine & Rigida & White pine & Cedar & Others \\
\cline { 3 - 6 } $\begin{array}{c}\text { Needle-leaf } \\
\text { trees }\end{array}$ & $\begin{array}{c}519,032 \\
(100)\end{array}$ & $\begin{array}{c}387,962 \\
(75)\end{array}$ & $\begin{array}{c}84,303 \\
(16)\end{array}$ & $\begin{array}{c}17,898 \\
(3)\end{array}$ & $\begin{array}{c}17,574 \\
(3)\end{array}$ & $\begin{array}{c}7,657 \\
(2)\end{array}$ & $\begin{array}{c}3,638 \\
(1)\end{array}$ \\
\cline { 3 - 7 } & & Oak & White Birch & Birch & Ash & Others \\
Broad- leaf & 40,631 & 104 & 826 & 629 & 576 & 496 \\
trees & $(100)$ & $(94)$ & $(2)$ & $(2)$ & $(1)$ & $(1)$ \\
\end{tabular}

Source: Forest Service. 2009 Research on the Actual Condition of Wood Application in 2008

Note: The value in ( ) is the component ratio. 
and Chungcheongbuk-do with 11\% (Korea Forest Service. 2009a).

In addition, it was found also that overall supply amount of domestic wood materials for lumbering was 559,663 and comprised 93\% of needle-leaf trees and 7\% of broad-leaf trees, showing that needle-leaf trees took the majority. By tree species, it was found that the needle- leaf trees consisted of $75 \%$ of larch, $16 \%$ of pine, $3 \%$ of Rigida, and 3\% of White pine. For broad-leaf trees, it was shown that oaks accounted for the majority, including other tree species such as white birch, birch, and ash
(Korea Forest Service. 2009b).

\section{Status of subject regions in case study}

Forest areas and white pine forest by ownerships

First, for the forest areas of Gapyeong-gun, the subject region of this survey, it was found that its total forest area, 69 thousand ha, consisted of 54\% of private forest, $32 \%$ of provincial forest, $13 \%$ of national forest, and $1 \%$ of military forest, where White pine forestaccounted for $30 \%$ of total forest area. The area ratio of white pine forest by ownerships consisted of $54 \%$ of private forest, $32 \%$

Table 3. Area of forest and white pine forest by ownerships in the subject regions

(Unit: ha)

\begin{tabular}{cccccc}
\hline Classification & Total & National forest & Provincial forest & Military forest & Private forest \\
\hline Gapyeong-gun & $\begin{array}{c}69,071 \\
(100)\end{array}$ & $\begin{array}{c}8,715 \\
(13)\end{array}$ & $\begin{array}{c}22,419 \\
(32)\end{array}$ & $\begin{array}{c}857 \\
(1)\end{array}$ & $\begin{array}{c}37,080 \\
(54)\end{array}$ \\
\hline White pine forest & $\begin{array}{c}0,651 \\
(100)\end{array}$ & $\begin{array}{c}1,173 \\
(6)\end{array}$ & $\begin{array}{c}5,385 \\
(26)\end{array}$ & unclear & 4,093 \\
$(68)$
\end{tabular}

Source: 1. Forest Service. 2009 Statistical Yearbook of Forestry

2. Gapyeong-gun. 2008 Planted area of white pine

Note: The value in () is the component ratio.

Table 4. Cutting status of Gapyeong-gun by tree species

\begin{tabular}{|c|c|c|c|c|c|c|c|c|c|c|c|c|c|c|c|c|c|c|c|}
\hline \multirow{2}{*}{\multicolumn{2}{|c|}{ Classification }} & \multicolumn{3}{|c|}{ Total } & \multicolumn{3}{|c|}{2005} & \multicolumn{3}{|c|}{2006} & \multicolumn{3}{|c|}{2007} & \multicolumn{3}{|c|}{2008} & \multicolumn{3}{|c|}{2009} \\
\hline & & Total & Thinning & $\begin{array}{l}\text { Clear } \\
\text { cutting }\end{array}$ & Subtotal & Thinning & $\begin{array}{c}\text { Clear } \\
\text { cutting }\end{array}$ & Subtotal & Thinning & $\begin{array}{c}\text { Clear } \\
\text { cutting }\end{array}$ & Subtotal & Thinning & $\begin{array}{l}\text { Clear } \\
\text { cutting }\end{array}$ & Subtotal & Thinning & $\begin{array}{l}\text { Clear } \\
\text { cutting }\end{array}$ & Subtotal & Thinning & $\begin{array}{l}\text { Clear } \\
\text { cutting }\end{array}$ \\
\hline \multirow{3}{*}{ Total } & $\begin{array}{l}\text { Forest } \\
\text { owner } \\
\text { (person) }\end{array}$ & $\begin{array}{c}414 \\
(100)\end{array}$ & $\begin{array}{l}303 \\
(73)\end{array}$ & $\begin{array}{l}111 \\
(27)\end{array}$ & 33 & 30 & 3 & 53 & 38 & 15 & 119 & 80 & 39 & 96 & 79 & 17 & 113 & 76 & 37 \\
\hline & $\begin{array}{l}\text { Area } \\
\text { (ha) }\end{array}$ & $\begin{array}{c}765 \\
(100)\end{array}$ & $\begin{array}{l}590 \\
(77)\end{array}$ & $\begin{array}{l}175 \\
(23)\end{array}$ & 61 & 56 & 5 & 74 & 57 & 17 & 191 & 147 & 44 & 164 & 146 & 18 & 275 & 184 & 91 \\
\hline & $\begin{array}{l}\text { Volume } \\
\left(\mathrm{m}^{3}\right)\end{array}$ & 22,560 & $\begin{array}{c}10,511 \\
(47)\end{array}$ & $\begin{array}{c}12,055 \\
(53)\end{array}$ & 1,606 & 977 & 629 & 2,453 & 1,348 & 1,105 & 4,910 & 2,196 & 2,714 & 4,527 & 2,941 & 1,586 & 9,071 & 3,049 & 6,022 \\
\hline \multirow{3}{*}{ White pine } & $\begin{array}{l}\text { Forest } \\
\text { owner }\end{array}$ & $\begin{array}{l}250 \\
(60)\end{array}$ & 220 & 30 & 24 & 22 & 2 & 31 & 28 & 3 & 61 & 54 & 7 & 60 & 53 & 7 & 74 & 63 & 11 \\
\hline & Area & $\begin{array}{l}513 \\
(67)\end{array}$ & 466 & 45 & 49 & 48 & 1 & 47 & 45 & 2 & 117 & 114 & 3 & 114 & 109 & 5 & 186 & 152 & 34 \\
\hline & Volume & $\begin{array}{c}11,311 \\
(50)\end{array}$ & 8,205 & 3,106 & 907 & 849 & 58 & 1,129 & 1,008 & 121 & 2,225 & 1,719 & 506 & 2,676 & 2,208 & 468 & 4,378 & 2,421 & 1,953 \\
\hline \multirow{3}{*}{ Larch } & $\begin{array}{l}\text { Forest } \\
\text { owner }\end{array}$ & 79 & 51 & 28 & 7 & 6 & 1 & 9 & 4 & 5 & 28 & 18 & 10 & 17 & 14 & 3 & 18 & 9 & 9 \\
\hline & Area & 97 & 68 & 29 & 8 & 4 & 4 & 10 & 5 & 5 & 28 & 20 & 8 & 20 & 15 & 5 & 31 & 24 & 7 \\
\hline & Volume & 4,747 & 1,492 & 3,255 & 661 & 91 & 570 & 803 & 249 & 554 & 1,021 & 356 & 665 & 800 & 372 & 428 & 1,462 & 424 & 1,038 \\
\hline \multirow{3}{*}{ Oak } & $\begin{array}{l}\text { Forest } \\
\text { owner }\end{array}$ & 51 & 25 & 26 & - & - & - & 7 & 5 & 2 & 13 & 7 & 6 & 13 & 9 & 4 & 18 & 4 & 14 \\
\hline & Area & 122 & 48 & 74 & - & - & - & 11 & 7 & 4 & 27 & 12 & 15 & 28 & 21 & 7 & 56 & 8 & 48 \\
\hline & Volume & 4,810 & 729 & 4,081 & - & - & - & 213 & 85 & 128 & 672 & 114 & 558 & 910 & 326 & 584 & 3,015 & 204 & 2,811 \\
\hline \multirow{3}{*}{$\begin{array}{c}\text { Rigida } \\
\text { Pine }\end{array}$} & $\begin{array}{l}\text { Forest } \\
\text { owner }\end{array}$ & 19 & 3 & 15 & - & - & - & 2 & - & 2 & 9 & 1 & 8 & 4 & 2 & 2 & 3 & - & 3 \\
\hline & Area & 24 & 2 & 22 & - & - & - & 5 & - & 5 & 15 & 1 & 14 & 2 & 1 & 1 & 2 & - & 2 \\
\hline & Volume & 1,880 & 35 & 1,338 & - & - & - & 270 & - & 270 & 761 & 7 & 754 & 122 & 28 & 94 & 220 & - & 220 \\
\hline \multirow{3}{*}{$\begin{array}{c}\text { Chestnut } \\
\text { tree }\end{array}$} & $\begin{array}{l}\text { Forest } \\
\text { owner }\end{array}$ & 7 & - & 7 & - & - & - & 1 & - & 1 & 6 & - & 6 & - & - & - & - & - & - \\
\hline & Area & 2 & - & 2 & - & - & - & - & - & - & 2 & - & 2 & - & - & - & - & - & - \\
\hline & Volume & 132 & - & 132 & - & - & - & 17 & - & 17 & 115 & - & 115 & - & - & - & - & - & - \\
\hline \multirow{3}{*}{ Others } & $\begin{array}{l}\text { Forest } \\
\text { owner }\end{array}$ & 8 & 3 & 5 & 1 & 1 & - & 3 & 1 & 2 & 2 & - & 2 & 2 & 1 & 1 & - & - & - \\
\hline & Area & 7 & 4 & 3 & 4 & 4 & - & 1 & - & 1 & 2 & - & 2 & - & - & - & - & - & - \\
\hline & Volume & 194 & 51 & 143 & 38 & 38 & - & 21 & 6 & 15 & 116 & - & 116 & 19 & 7 & 12 & - & - & - \\
\hline
\end{tabular}

Note: The number of forest owners is the total number of man-days. 
of provincial forest, and 13\% of national forest (Korea Forest Service, 2009a; Gapyeong-gun, 2008).

Status of cutting and forest owner by tree species in Gapyeong-gun

For the cutting record of Gapyeong-gun for 5 years from 2005 to 2009, it was found that number of the forest owners was 414 man-days, its cutting area was 765 ha, and its cutting volume was $22,560 \mathrm{~m}^{3}$. It was true that its cutting amount was increasing every year. While thinning accounted for $73 \%$ of total forest owners and $77 \%$ of the cutting area, clear cutting accounted for 53\% of the cutting volume. By tree species, it was found that cutting ration of white pine was the highest (Gapyeonggun. 2010a; Gapyeong-gun. 2010b; Gapyeong-gun. 2010c).

For the status of forest owner location, it was found that the ratio of resident forest owners who lived in Gapyeong-gun was $42 \%$ and they accounted for $44 \%$ of the area and $37 \%$ of the volume. For the absentee forest owner, Seoul and Gyeonggi accounted for the majority as 23\% and 22\% (Gapyeong-gun. 2010a; Gapyeong-gun. 2010b; Gapyeong-gun. 2010c).

For cutting status by forest owning scales, it was found that forest owner classes having less than 1 ha and $1 \sim 3$ ha had $41 \%$ and $43 \%$ of total forest owners respectively, forest owner classes having 1 3 ha and less than 5 ha accounted for $40 \%$ and $27 \%$ of the area, and forest owner classes having 1 3 ha and less than 5 ha accounted for $44 \%$ and $21 \%$ of the volume (Gapyeong-gun. 2010a; Gapyeong-gun. 2010b; Gapyeong-gun. 2010c).

\section{Case Study}

Forest owning structure and tree species composition

Mean age of 41 forest owners, the subjects of this survey, was 57 years old and persons in his fifties and sixties was the most as 13 and 11 persons respectively.

Table 5. Cutting status of Gapyeong-gun by locations of its forest owners

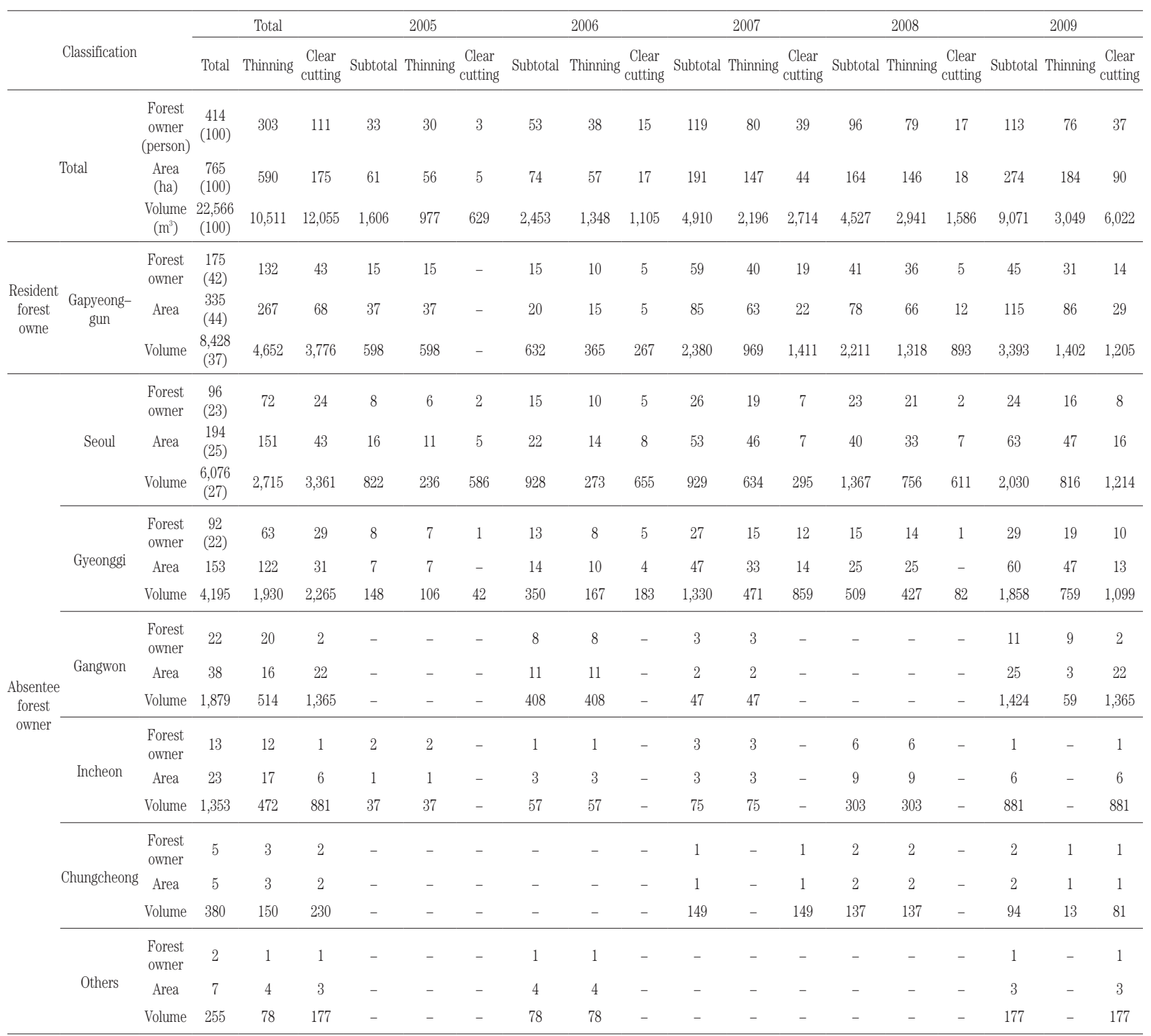


Table 6. Cutting status of Gapyeong-gun by forest owning scales

\begin{tabular}{|c|c|c|c|c|c|c|c|c|c|c|c|c|c|c|c|c|c|c|c|}
\hline \multirow{2}{*}{\multicolumn{2}{|c|}{ Classification }} & \multicolumn{3}{|c|}{ Total } & \multicolumn{3}{|c|}{2005} & \multicolumn{3}{|c|}{2006} & \multicolumn{3}{|c|}{2007} & \multicolumn{3}{|c|}{2008} & \multicolumn{3}{|c|}{2009} \\
\hline & & Total & Thinning & $\begin{array}{l}\text { Clear } \\
\text { cutting }\end{array}$ & Subtotal & Thinning & $\begin{array}{l}\text { Clear } \\
\text { cutting }\end{array}$ & Subtotal & Thinning & $\begin{array}{l}\text { Clear } \\
\text { cutting }\end{array}$ & Subtotal & Thinning & $\begin{array}{l}\text { Clear } \\
\text { cutting }\end{array}$ & Subtotal & Thinning & $\begin{array}{l}\text { Clear } \\
\text { cutting }\end{array}$ & Subtotal & Thinning & $\begin{array}{l}\text { Clear } \\
\text { cutting }\end{array}$ \\
\hline \multirow{3}{*}{ Total } & $\begin{array}{c}\text { Forest } \\
\text { owner } \\
\text { (person) }\end{array}$ & $\begin{array}{c}414 \\
(100)\end{array}$ & 303 & 111 & 33 & 30 & 3 & 53 & 38 & 15 & 119 & 80 & 39 & 96 & 79 & 17 & 113 & 76 & 37 \\
\hline & $\begin{array}{l}\text { Area } \\
\text { (ha) }\end{array}$ & $\begin{array}{c}765 \\
(100)\end{array}$ & 590 & 175 & 61 & 56 & 5 & 74 & 57 & 17 & 191 & 147 & 44 & 164 & 146 & 18 & 275 & 184 & 91 \\
\hline & $\begin{array}{l}\text { Volume } \\
\left(\mathrm{m}^{3}\right)\end{array}$ & $\begin{array}{c}22,566 \\
(100)\end{array}$ & 10,511 & 12,055 & 1,606 & 977 & 629 & 2,453 & 1,348 & 1,105 & 4,910 & 2,196 & 2,714 & 4,527 & 2,941 & 1,586 & 9,071 & 3,049 & 6,022 \\
\hline \multirow{3}{*}{$<$ lha } & $\begin{array}{l}\text { Forest } \\
\text { owner }\end{array}$ & $\begin{array}{l}169 \\
(41)\end{array}$ & 112 & 57 & 14 & 12 & 2 & 31 & 19 & 12 & 56 & 34 & 22 & 38 & 27 & 11 & 30 & 20 & 10 \\
\hline & Area & $\begin{array}{c}93 \\
(12)\end{array}$ & 59 & 34 & 7 & 6 & 1 & 15 & 11 & 4 & 23 & 15 & 8 & 20 & 14 & 6 & 28 & 13 & 15 \\
\hline & Volume & $\begin{array}{c}3,519 \\
(16)\end{array}$ & 1,505 & 2,014 & 188 & 129 & 58 & 584 & 310 & 274 & 1,093 & 359 & 734 & 799 & 366 & 432 & 857 & 341 & 516 \\
\hline \multirow{3}{*}{ 1 3ha } & $\begin{array}{l}\text { Forest } \\
\text { owner }\end{array}$ & $\begin{array}{l}177 \\
(43)\end{array}$ & 139 & 38 & 14 & 14 & - & 15 & 14 & 1 & 44 & 32 & 12 & 47 & 41 & 6 & 57 & 38 & 19 \\
\hline & Area & $\begin{array}{l}304 \\
(40)\end{array}$ & 239 & 65 & 20 & 20 & - & 28 & 25 & 3 & 75 & 57 & 18 & 84 & 72 & 12 & 97 & 65 & 32 \\
\hline & Volume & $\begin{array}{l}9,983 \\
(44) \\
\end{array}$ & 4,803 & 5,180 & 379 & 379 & - & 668 & 579 & 89 & 2,037 & 855 & 1,182 & 2,904 & 1,750 & 1,154 & 3,995 & 1,240 & 2,755 \\
\hline \multirow{3}{*}{$3 \sim 5 \mathrm{ha}$} & $\begin{array}{l}\text { Forest } \\
\text { owner }\end{array}$ & $\begin{array}{c}41 \\
(10)\end{array}$ & 29 & 12 & 3 & 2 & 1 & 5 & 4 & 1 & 14 & 9 & 5 & 7 & 7 & - & 12 & 7 & 5 \\
\hline & Area & $\begin{array}{l}158 \\
(21)\end{array}$ & 114 & 44 & 11 & 7 & 4 & 18 & 14 & 4 & 56 & 39 & 17 & 29 & 29 & - & 44 & 25 & 19 \\
\hline & Volume & $\begin{array}{c}4,392 \\
(19)\end{array}$ & 1,735 & 2,657 & 659 & 89 & 570 & 461 & 299 & 162 & 1,331 & 533 & 798 & 440 & 440 & - & 1,501 & 374 & 1,127 \\
\hline \multirow{3}{*}{$>5 \mathrm{ha}$} & $\begin{array}{l}\text { Forest } \\
\text { owner }\end{array}$ & $\begin{array}{l}27 \\
(7)\end{array}$ & 23 & 4 & 2 & 2 & - & 2 & 1 & 1 & 5 & 5 & - & 4 & 4 & - & 14 & 11 & 3 \\
\hline & Area & $\begin{array}{l}210 \\
(27)\end{array}$ & 178 & 32 & 23 & 23 & - & 13 & 7 & 6 & 37 & 37 & - & 31 & 31 & - & 106 & 81 & 25 \\
\hline & Volume & $\begin{array}{l}672 \\
(21)\end{array}$ & 2,468 & 2,204 & 380 & 380 & - & 740 & 160 & 580 & 449 & 449 & - & 385 & 385 & - & 2,718 & 1,094 & 1,624 \\
\hline
\end{tabular}

Note: The number of forest owners is the total number of man-days.

The forest owners in his forties and seventies was 6 persons respectively and the forest owner in his thirties was 5 persons. While the forest owning scale was 5.1 ha per forest owner, the number of forest owners with less than 1 ha was 4, 1 3 ha was 16, 3 5 ha was 9, 5 10 ha was 6 and above 10 ha was 6 .

For tree species of the owned forest, it was found that white pine took the greatest part as $75 \%$, followed by $12 \%$ of Oak and $9 \%$ of Pine and the white pine accounting for the largest part was mainly 30 40 years old.

Although there was a case that Larch was planted newly after clear cutting, 30 40 year old trees accounted for the majority of them (Table 7).

Forest commencement and future plan

For status of forest commencement, it was found that 10 persons among 41 forest owners executed removal of miscellaneous trees and vines and pruning and that by their ages, the forest owners in 50's accounted for the highest ratio as 6 persons among the 13 forest owners. 1 fruit tree planning and 1 industrial crop planting forest owner planted mulberry and wood-cultivated ginseng respectively. For forest production, it was found that fuel was 4 , fruit harvest was 2 , and wild edible greens was 1 and the fuel was for heating, the fruit was pine nuts

Table 7. Composition by tree species

(Unit: ha)

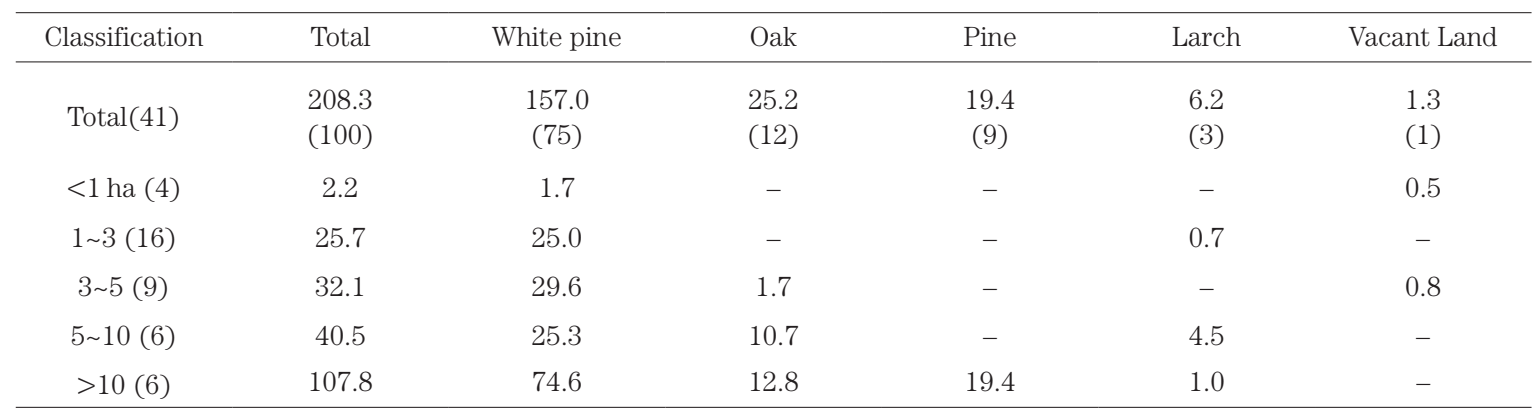

Note: 1. Value in ( ) of the above Classification is number of forest owners.

2. The value in ( ) is the component ratio. 
and the wild edible greens was bud of aralia elater. However there was no income by selling them excluding 10.3 million won of 2 pine nut producing owners because the fuel and the wild greens was for their own use. For pine nut gathering, they answered that although the pine nut gathering was still active due to pine nut processing plants locating nearly and that the number of pine nut collectors was decreasing by reason of rising labor cost, risk bearing and decrease of fruiting amount.

For the center of household economy, it was found that agriculture took the largest part as 23 persons in 41 subjects and when the age was lower and the forest owning scale was smaller, the number of answers that center of household economy was business owner and live stock was more. For managing land scale, it was shown that the number of persons who answered maintenance of quo was the most as 29 persons. However, 8 persons who answered to wish expansion included 3 persons for agriculture, 3 persons for property, and 2 persons with no response and 4 persons who answered reduction involved 1 person from lack of labor, 1 person from low profitability, and 2 persons from economic circumstances.

For forest land, it was found that 6 persons who answered expansion involved 2 persons for property value, 1 person for land reclamation, 1 person for timber merchant, 1 person for operation of training institute, and 1 person for pine nut gathering. The persons who answered maintenance of quo included 6 persons for

Table 8. Forest commencement and production state (during recent 5 years)

(Unit: person)

\begin{tabular}{|c|c|c|c|c|c|c|c|c|c|}
\hline \multirow{2}{*}{\multicolumn{2}{|c|}{ Classification }} & \multicolumn{4}{|c|}{ Commencement } & \multicolumn{3}{|c|}{ Production } & \multirow[b]{2}{*}{ Wild greens } \\
\hline & & Total & $\begin{array}{l}\text { Removal of } \\
\text { miscellaneous } \\
\text { trees and vines } \\
\text { pruning }\end{array}$ & $\begin{array}{c}\text { Fruit tree } \\
\text { planting }\end{array}$ & $\begin{array}{l}\text { Industrial } \\
\text { crop planting }\end{array}$ & Total & Fuel & Fruits & \\
\hline \multicolumn{2}{|c|}{ Total } & 12 & 10 & 1 & 1 & 7 & 4 & 2 & 1 \\
\hline \multirow{5}{*}{ By ages } & 30 's (5) & 1 & 1 & - & - & 2 & 1 & - & 1 \\
\hline & 40 's (6) & 2 & - & 1 & 1 & 2 & 1 & 1 & - \\
\hline & 50’s (13) & 6 & 6 & - & - & 3 & 2 & 1 & - \\
\hline & 60's (11) & 2 & 2 & - & - & - & - & - & - \\
\hline & $>70$ 's $(6)$ & 1 & 1 & - & - & - & - & - & - \\
\hline \multirow{5}{*}{$\begin{array}{c}\text { By forest } \\
\text { owning } \\
\text { scales }\end{array}$} & $<1$ ha(4) & & - & - & - & 1 & - & 1 & - \\
\hline & $1 \sim 3 \mathrm{ha}(16)$ & 4 & 3 & - & 1 & 3 & 1 & 1 & 1 \\
\hline & $3 \sim 5$ ha(9) & 3 & 3 & - & - & 2 & 2 & - & - \\
\hline & $5 \sim 10$ ha(6) & 4 & 3 & 1 & - & - & - & - & - \\
\hline & $>10$ ha(6) & 1 & 1 & - & - & 1 & 1 & - & - \\
\hline
\end{tabular}

Note: The value in ( ) in the above Classification is the number of forest owners.

Table 9. Agro-forestry management plan

(Unit: person)

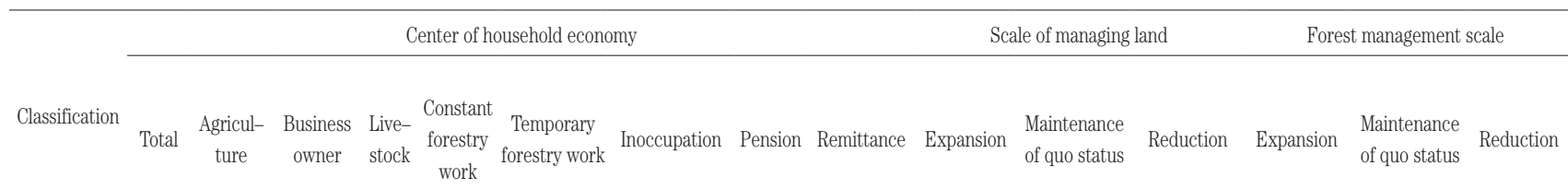

\begin{tabular}{|c|c|c|c|c|c|c|c|c|c|c|c|c|c|c|c|c|}
\hline \multicolumn{2}{|c|}{ Total } & $\begin{array}{c}41 \\
(100)\end{array}$ & $\begin{array}{c}23 \\
(56)\end{array}$ & 8 & 3 & 3 & 1 & 1 & 1 & 1 & 8 & $\begin{array}{c}29 \\
(71)\end{array}$ & 4 & 6 & $\begin{array}{c}28 \\
(68)\end{array}$ & 7 \\
\hline \multirow{5}{*}{$\begin{array}{c}\text { By } \\
\text { ages }\end{array}$} & 30 's & 5 & 1 & 2 & 1 & - & 1 & - & - & - & 4 & 1 & - & 3 & 1 & 1 \\
\hline & 40 's & 6 & 2 & 1 & 1 & 2 & - & - & - & - & 2 & 4 & - & 2 & 3 & 1 \\
\hline & 50 's & 13 & 8 & 3 & - & 1 & - & 1 & - & - & - & 10 & 3 & 1 & 9 & 3 \\
\hline & 60 's & 11 & 8 & 2 & - & - & - & - & 1 & - & 1 & 9 & 1 & - & 9 & 2 \\
\hline & $>70$ 's & 6 & 4 & - & 1 & - & - & - & - & 1 & 1 & 5 & - & - & 6 & - \\
\hline \multirow{5}{*}{$\begin{array}{c}\text { By } \\
\text { forest } \\
\text { owning } \\
\text { scales }\end{array}$} & $<1$ ha & 4 & 2 & - & & 2 & - & - & - & - & 1 & 2 & 1 & - & 3 & 1 \\
\hline & $1 \sim 3$ & 8 & 8 & 5 & 1 & - & 1 & - & - & 1 & 5 & 11 & - & 5 & 11 & - \\
\hline & $3 \sim 5$ & 9 & 6 & 2 & 1 & - & - & - & - & - & 2 & 6 & 1 & - & 7 & 2 \\
\hline & $5 \sim 10$ & 6 & 4 & - & 1 & 1 & - & - & - & - & - & 6 & - & - & 4 & 2 \\
\hline & $>10$ & 6 & 3 & 1 & - & - & - & 1 & 1 & - & - & 4 & 2 & 1 & 3 & 2 \\
\hline
\end{tabular}

Note: The value in ( ) is the component ratio. 
property value and 22 persons for succession and all of 7 persons planning reduction answered low profitability.

Status of cutting area and volume

Total cutting area and cutting volume of 41 forest owners, the subjects of this survey was 72.2 ha and $1,651 \mathrm{~m}^{3}$ and among them, thinning accounted for the majority as 67.1 ha and $1,389 \mathrm{~m}^{3}$ respectively. The cutting area and cutting volume per forest owner was 1.8 ha and $40.3 \mathrm{~m}^{3}$, but 40 forest owners executed the cutting work by requesting timbering merchants and 1 owners did it by requesting the Forest Association. As shown in the above results, the reason for the most of forest owners to request the cutting work to the timber dealer was that the timer dealer carried out all of administrative procedures as proxy of forest owner to reduce troubles in the forest owner position. In addition, as the timber dealers lived in same or adjacent regions, it was easy for the forest owners to request cutting. And, it was impossible practically to fell forest trees by its owner because of problems such as lack of labors and equipments and most of forest owners didn't know existence and role of the forest association well. Besides, although most of

Table 10. Cutting area and cutting volume

\begin{tabular}{ccccc}
\hline \multicolumn{2}{c}{ Classification } & Total & Clear cutting & Thinning \\
\hline \multirow{2}{*}{ Total } & Area (ha) & $72.2(100)$ & $5.1(7)$ & $67.1(93)$ \\
& Volume $\left(\mathrm{m}^{3}\right)$ & $1,651(100)$ & $262(16)$ & $1,389(84)$ \\
\hline \multirow{2}{*}{ White pine } & Area (ha) & $71(98)$ & 4.4 & 66.6 \\
& Volume $\left(\mathrm{m}^{3}\right)$ & $1,592(96)$ & 223 & 1,369 \\
\hline \multirow{2}{*}{ Oak } & Area (ha) & 0.7 & 0.7 & - \\
& Volume (m) & 39 & 39 & 0.5 \\
Larch & Area (ha) & 0.5 & - & 20 \\
\hline
\end{tabular}

Note: The value in ( ) is the component ratio.

Table 11. Cutting area and cutting volume

\begin{tabular}{|c|c|c|c|c|c|c|c|c|c|c|}
\hline \multicolumn{2}{|c|}{ Classification } & $\begin{array}{c}\text { Forest } \\
\text { area } \\
\text { (ha) }\end{array}$ & $\begin{array}{c}\text { Cutting } \\
\text { area } \\
\text { (ha) }\end{array}$ & $\begin{array}{c}\text { Cutting } \\
\text { volume } \\
\left(\mathrm{m}^{3}\right)\end{array}$ & $\begin{array}{c}\text { Cutting } \\
\text { income } \\
\text { (10 thousand } \\
\text { won) }\end{array}$ & $\begin{array}{l}\text { Cutting area/ } \\
\text { forest area } \\
\text { (\%) }\end{array}$ & $\begin{array}{l}\text { Cutting } \\
\text { volume/ } \\
\text { cutting } \\
\text { area } \\
\text { (ha) }\end{array}$ & $\begin{array}{c}\text { Income/ } \\
\text { owner } \\
\text { (10 thousand } \\
\text { won) }\end{array}$ & $\begin{array}{c}\text { Income/ } \\
\text { cutting } \\
\text { area } \\
\text { (10 thousand } \\
\text { won) }\end{array}$ & $\begin{array}{c}\text { Income/ } \\
\text { cutting } \\
\text { volume } \\
\text { (10 thousand } \\
\text { won) }\end{array}$ \\
\hline \multicolumn{2}{|c|}{$\begin{array}{l}\text { Total } \\
(41)\end{array}$} & 208.3 & 72.2 & 1,651 & $\begin{array}{c}10,020 \\
(35)\end{array}$ & 35 & 23 & 286 & 139 & 6 \\
\hline \multirow{5}{*}{ By ages } & $\begin{array}{l}30 \text { 's } \\
(5)\end{array}$ & 7.3 & 5.6 & 135 & $\begin{array}{c}1,050 \\
(4)\end{array}$ & 77 & 24 & 263 & 188 & 8 \\
\hline & $\begin{array}{l}40 \text { 's } \\
(6)\end{array}$ & 25.2 & 6.3 & 117 & $\begin{array}{l}520 \\
(4)\end{array}$ & 25 & 19 & 130 & 83 & 4 \\
\hline & $\begin{array}{l}\text { 50's } \\
\text { (13) }\end{array}$ & 49.4 & 17.4 & 602 & $\begin{array}{c}2,430 \\
(10)\end{array}$ & 35 & 35 & 243 & 140 & 4 \\
\hline & $\begin{array}{l}\text { 60's } \\
\text { (11) }\end{array}$ & 104.6 & 27.8 & 456 & $\begin{array}{c}3,520 \\
(11)\end{array}$ & 27 & 16 & 320 & 127 & 8 \\
\hline & $\begin{array}{c}>70 \text { 's } \\
(6)\end{array}$ & 21.8 & 15.1 & 341 & $\begin{array}{c}2,500 \\
(6)\end{array}$ & 69 & 23 & 417 & 166 & 7 \\
\hline \multirow{5}{*}{$\begin{array}{c}\text { By forest } \\
\text { owning } \\
\text { scales }\end{array}$} & $\begin{array}{c}<1 \text { ha } \\
(4)\end{array}$ & 2.2 & 2.2 & 61 & $\begin{array}{l}50 \\
(1)\end{array}$ & 100 & 28 & 50 & 23 & 1 \\
\hline & $\begin{array}{l}1 \sim 3 \\
(16)\end{array}$ & 25.7 & 20.1 & 545 & $\begin{array}{c}3,030 \\
(15)\end{array}$ & 63 & 27 & 202 & 151 & 6 \\
\hline & $\begin{array}{l}3 \sim 5 \\
(9)\end{array}$ & 32.1 & 21.6 & 398 & $\begin{array}{c}4,050 \\
(9)\end{array}$ & 67 & 18 & 450 & 188 & 10 \\
\hline & $\begin{array}{c}5 \sim 10 \\
(6)\end{array}$ & 40.5 & 14.6 & 242 & $\begin{array}{c}1,970 \\
(5)\end{array}$ & 36 & 17 & 394 & 135 & 8 \\
\hline & $\begin{array}{l}>10 \\
(6)\end{array}$ & 107.8 & 13.7 & 405 & $\begin{array}{l}920 \\
(5)\end{array}$ & 13 & 30 & 184 & 67 & 2 \\
\hline
\end{tabular}

Note: 1. Value in ( ) of the above classification is number of forest owners.

2 . Value in ( ) of the income was the number of forest owners with income.

3. Clear cutting area was 5.1ha and clear cutting volume was $26.2 \mathrm{~m}^{3}$.

4. For the income/owner (10 thousand won), only forest owner with income was applied. 
the forest owners answered that they would request also their cutting related works to timber dealers in future, the one-sided presentation of timber price by the subjectivity of timber dealers may cause problems including low income of the forest owner and may be connected to lowering of willing for forest management.

For cutting status of 41 subjects, it was found that the ratio of cutting area against forest area was the largest in 30's as 77\% and by forest owning scales, it was shown that the class with $<1$ ha was the highest as 100\%, but when the scale was greater, the cutting ratio was lower. The cutting volume per ha was 23 and average cutting income of 35 forest owners who had had cutting income was 2.86 million won. The cutting income per ha was 1.39 million won and the timber price per volume was 10 100 thousand won, averaging 60 thousand won. Besides, as it was needed to estimate forest tree volume of the subject forest land in order to fix the price of forest tree, but the timber dealers estimate the forest tree price from total volume regardless of tree species including white pine, larch and oak to present it to the forest owners. For the presented price of forest trees, the forest owners would agree, or when they were unsatisfied with it, price adjustment between the dealer and the owner would be done. And, it was found that the reason that the unit price of forest tree per volume was different in spite of same tree species was because it was influenced largely from geographical conditions of forest land such as timber carry-out distance and slope and timber condition such as thickness and insect pest damage. Thus, it was suggested that the unit price per volume was not associated greatly with cutting area and volume. Forest owners with no income were the cases that a timber dealer took their forest trees without charge for cutting charge. Most of these cases were that quality of trees was not so good or they were thin, cutting land was rapid slope, or its geographical condition was poor from long carry-out distance. Besides, the price of domestic timber per as of December, 2008 was 200 thousand won of pine, 110 thousand won of larch, 90 thousand of ordinary noncoifers, 70 thousand won of pit prop wood, and 60 thousand won of pulp wood (Kang and Kohroki, 2008b).

Difficulties on forest management

For difficulties on forest management, most of forest owners answered low profitability. The purpose of expansion of forest management scale included property value, reclamation, and operation of training institute rather than true forest management and the forest owners wishing reduction accounted for $17 \%$. In addition, most forest owners including possessing forest for the purpose of ancestral burial ground and property value answered that they were unsatisfied to tax imposed every year in spite of no income from the forest rather than to support from the government.

\section{CONCLUSION}

1. Among the major needle-leaf trees in Korea, white pine forest accounted for $5 \%$ of total forest area and
9\% of need-leaf forest area and among the needle leaf trees, the regions with higher ratio of white pine forest were $34 \%$ of Gyeonggi-do, $16 \%$ of Gangwon-do, and 11\% of Chungcheongbuk-do.

2. The white pine forest of Gapyeong-gun, the subject region of this survey, accounted for $30 \%$ of its total forest area and the area ratio of white pine forest by ownerships consisted of $54 \%$ of private forest, $32 \%$ of provincial forest, and $13 \%$ of national forest.

3. For the cutting record of Gapyeong-gun for 5 years from 2005 to 2009, it was found that number of the forest owners was 414 man-days, its cutting area was $765 \mathrm{ha}$, and its cutting volume was $22,560 \mathrm{~m}^{3}$. The cutting ratio of white pine was the highest.

4. Mean age of 41 forest owners, the subjects of this survey, was 57 years old and persons in his fifty and sixty was the most as 13 and 11 persons respectively. Their forest owning scale was 5.1 per forest owner. White pine accounted for the greatest part as $75 \%$, which were mainly 30-40 years old.

5. Total cutting area and cutting volume of 41 forest owners, the subjects of this survey was 72.2 ha and $1,651 \mathrm{~m}^{3}$ and among them, thinning accounted for the majority as 67.1 ha and $1,389 \mathrm{~m}^{3}$ respectively. The cutting area and cutting volume per forest owner was 1.8 ha and $40.3 \mathrm{~m}^{3}$, but 40 forest owners executed the cutting work by requesting timbering merchants and 1 owner did it by requesting the Forest Association.

6. The cutting volume per ha was $23 \mathrm{~m}^{3}$ and average cutting income of 35 forest owners with cutting income was 2.86 million won. The cutting income per ha was 1.39 million won and the timber price per volume was 10 100 thousand won, averaging 60 thousand won.

Therefore, in order to activate forest management as well as white pine forest of Gapyeong-gun, it is considered that following measures should be prepared.

1. Forest cutting by forest owner's own strength is impossible practically because of insufficient labor and equipments. Thus, it is needed to induce their interest on forest management by providing convenience and brining more profit to them through active execution of cutting by the Forest Association, which is an organization for the forest owners and supported by the government.

2. Although the felled white pine timbers were sold 60 thousand won per on the average, but it was the level of pulp wood price. In order to secure higher timber price in future, it is required to try to produce good quality wood via forest commencement including pruning and thinning and it seems that a measure to support the forest commencement budget preferentially to the forest owners who are active in forest management is also needed.

3. It was found that the unit price of forest tree per volume was influenced greatly by several factors such as timer carry-out distance, slope, thickness, and damage of insect pest. Therefore, it is required to 
raise productivity of forest management through continuous promotion of private forest management system establishment project by the government.

4. Finally, it is urgent to improve forest taxation system including exemption of tax imposed on forest with no income and it is also required to prepare a measure to raise insufficient financial resources for forest commencement through introduction of local government specific systems such as forest environment tax by considering long term feature and low profitability, which are specific for forest management. And the government should try to bring up forest owners aiming at forest management rather than ancestral burial ground or property value by promoting an internal economization measure for public benefit functional of forest.

\section{REFERENCES}

Byung Soo Seo. Sang Hyun Lee. Hag Mo Kang. 1999 A Study on the Management Situation of Private Forest Belonged to Non-Resident Owners-Focused on Chonbuk Regions-. Korean Journal of Forest Economics, 7(2): 19-31

Gapyeong-gun. 2008 Planted area of white pine

Gapyeong-gun. 2010a Stumpage cutting permission

Gapyeong-gun. 2010b Stumpage cutting report

Gapyeong-gun. 2010c Forest management plan forest project report

Hag Mo Kang,Katsuhisa Kohroki. 2008a A Study on Forestry Successors in Korea Focused on Successors in Gueonggi Province. Journal of the Faculty of Agriculture Kyushu University, $\mathbf{5 3}$ (1): 281-289

Hag Mo Kang,Katsuhisa Kohroki. 2008b A Study on the Mountain Village Income Increase Project. Journal of the Faculty of Agriculture Kyushu University, 53(2): 563-568

Jae-Seong Kim. 2010 Survey on actual condition of forestry management. Korea Forest Research Institute. Forest Scientific Information, 228(4): 20-21

Korea Forest Service. 2007 The $5^{\text {th }}$ Forest Basic Planning (2008 2017)

Korea Forest Service. 2009a Statistical Yearbook of Forestry Korea Forest Service. 2009b Research on the Actual Condition of Wood Application in 2008

Korea Forest Service. 2010 Detailed promotion plan of major projects in 2010 